\title{
Science as a Form of Life and Cross-disciplinarity: Mariano Artigas and Charles S. Peirce
}

\author{
JAIME NUBIOLA* \\ Universidad de Navarra (University of Navarra, Spain) \\ jnubiola@unav.es
}

\begin{abstract}
According to Charles S. Peirce and to Mariano Artigas, science is the collective and cooperative activity of all those whose lives are animated by the desire to discover the truth. The particular sciences are branches of a common tree. The unity of science is not achieved by the reduction of the special sciences to more basic ones: the new name for the unity of the sciences is cross-disciplinarity. This is not a union of the sciences themselves, but rather the unity and dialogue of scientists, the real inquirers into the truth. In the light of Peirce's and Artigas's teachings, we can see that philosophers are in just the right place to call for this unity of sciences. This call should not be seen as promoting a return to the old scientism, but seeks a deep dialogue between the particular sciences and philosophy in order to deal with the presuppositions of the scientific enterprise. The key to the cross-disciplinarity of knowledge is not revolution, but rather shared efforts in a unique mixture of continuity and fallibilism, of affection and reason, of the attempt to understand others' disciplines as well as our own.
\end{abstract}

Keywords: philosophy; unity of science; classification of the sciences; cross-disciplinarity; dialogue.

I want to express my gratitude for Prof. Santiago Collado's invitation to take part in this special issue on my admired professor and colleague Mariano Artigas. Some paragraphs come from the papers by Jaime Nubiola $(2005,2014)$ as well as the volume co-authored with Sara Barrena (2014, 437-442).

ScientiaetFides $4(2) / 2016,303-317$ 


\section{Introduction}

In this paper I want to bring together two eminent philosophers of science: Charles S. Peirce (1839-1914) and Mariano Artigas (1938-2006). First I will share some personal memories from my encounter with Artigas (section 2), followed by the presentation of Charles S. Peirce as a scientist and philosopher (section 3). The heart of the paper is my description of Peirce's conception of what a science really is (section 4), his classification of the sciences (section 5) and certain consequences of this conception when applied to scientific communication and cross-disciplinarity (section 6). In particular I pay close attention to Artigas' vision of cross-disciplinarity and the role of philosophy in cross-disciplinary dialogue.

It seems to me that the students and colleagues of Artigas, and now his readers, can attest that, like Charles S. Peirce, Artigas was a real scientist-philosopher: his life was always characterized by his eagerness to learn and the love with which he taught others. In particular, we can learn from their efforts to pursue a real dialogue between the sciences, with philosophy serving as their bridge.

\section{A brief personal remembrance}

I met Professor Artigas during my first two years at university in Barcelona, between 1970 and 1972. Mariano Artigas, who was then 32 years old, was assistant professor of philosophy of nature at the University, while at the same time writing his doctoral thesis on Karl R. Popper. At the same time he was chaplain at Colegio Mayor Monterols, a university residence where I was staying. In the summer of 1970 I attended his course "Philosophy of Nature", and during those two years I talked regularly with him. Right from the beginning, I saw him as a genuine scientist-philosopher who reflected on the methodological success of the scientific enterprise and sought to integrate in a single field of intellectual activity his sound scientific knowledge, his philosophical acuity and his deep Catholic faith.

In particular, I have two memories of this stage: first, the two volumes of Husserl's Logical Investigations that Artigas gave me and that I still keep 
in my personal library: that book gave a great impulse to my philosophical vocation. Second, I helped him to write a letter to Popper asking if the rumor was true that he had published a new book, entitled Corroborations and Refutations. A new book would have forced Artigas to modify his doctoral thesis, then in progress. We had no email or internet in those days, and so we had to wait for the post to come. I remember the excitement with which we read Popper's response letter, in which he said that-among other things-he had not written that book.

I met Mariano Artigas again fifteen years later when he moved to the University of Navarra to work as the Dean of the newly created Ecclesiastical Faculty of Philosophy in 1988. At that time I was starting my job as assistant professor of philosophy after twelve years of intense dedication to management of the university. I went with Artigas to the 9th International Congress of Logic, Methodology and Philosophy of Science, held in Uppsala in August 1991. There he introduced me to Evandro Agazzi, René Thom and other luminaries of the time. His paper on "Reliability and Fallibilism" was very well received and generated an extremely interesting dialogue afterwards. I was deeply impressed by the fact that Artigas did not try to hide the fact that he was a Catholic priest, as well as by the warm appreciation and deep respect with which everyone treated him.

In 1994, with three doctoral students, I started a Charles S. Peirce Studies Group in Navarra. Its aim was to promote the study of the work of Charles S. Peirce, especially in Spain and the Spanish speaking countries, in the belief that his thought might offer key insights into problems related to the culture, science and philosophy of the 21st century. The Group offered a platform for an exchange of ideas regarding the work of Peirce, American pragmatism, its reception in Europe and in the Hispanic world, and related topics. Since its inception, the activities of the Group were supported by Mariano Artigas, and have included the participation of scholars from different fields, including history, linguistics, literature, philosophy of science, law, communication studies and theology. In fact, Artigas' support was essential for obtaining funding for the Group's projects from 1995 until 2002. We are very grateful to him. 
Perhaps one of the most relevant fruits of this cooperation is the monographic issue of the journal Anuario Filosófico (2001, 34/1) on "Charles S. Peirce and Karl R. Popper: Philosophy of Science of the 20th Century”, which included papers by Susan Haack, Guy Debrock, Douglas Niño, Carlos Ortiz de Landázuri, Juan Arana, Josep Corcó, Jaume Navarro and Hubert Kiesewetter, besides Artigas' paper on "Logic and Ethics in Karl Popper". ${ }^{1}$ In addition, there was the superb collection of seminars on interdisciplinarity held during the years 2001 and 2002, with the participation of Evandro Agazzi, Juan Arana and Mariano Artigas himself, amongst others.

In spring of 2002, I had a long two-hour conversation with Artigas, walking pleasantly about the beautiful campus of the University. Artigas felt something like a calling or a duty to launch his own research group on science, reason and faith, giving up his immediate cooperation with the Peirce Group. I understood very well what he was planning and encouraged him to develop that undertaking, which would have my support. I grasped, in that conversation, that the CRYF was to be his enduring last project.

\section{Charles S. Peirce, a scientist philosopher}

Although Charles S. Peirce was a philosopher and a logician, he was first and foremost a real practitioner of science. Not only was he trained as a chemist at Harvard, but for thirty years (1861-1891) he worked regularly and strenuously for the U. S. Coast Survey as a metrologist and as an observer in astronomy and geodesy. His reports to the Coast Survey are an outstanding testimony to his personal experience in the hard work of measuring and obtaining empirical evidence.

A glance at his Photometric Researches, produced during the years 1872-75, immediately confirms the impression of a man involved in solid scientific work $(W 3,382-493){ }^{2}$ I agree with Victor Lenzen $(1964,33)$ that

1 The volume is available at <http://www.unav.es/gep/AF69/AF69Artigas.html>.

2 In referring to Peirce's texts I use the following abbreviations (followed by the volume number, the paragraph number and the year of the text): $[C P]$ 1931-1958. Collected Papers of Charles Sanders Peirce, vols. 1-8, edited by C. Hartshorne, P. Weiss and A. W. Burks. 
"Peirce's scientific work is relevant to his philosophy, for his philosophical doctrines indicate the influence of his reflective thought upon the methods of science," and with Ketner's judgment, "Peirce was not a dilettante in science, but a master scientist.” $(2009,42)$ To summarize all this in Fisch's words (1993), "Peirce was not merely a philosopher or a logician who had read up on science. He was a full-fledged professional scientist, who carried into all his work the concerns of the philosopher and logician.”

Peirce's personal participation in the scientific community of his time buttresses what he has to say about science from a philosophical point of view. Having done research in astronomy, mathematics, logic and philosophy, as well as in the history of all these sciences, Peirce tried all his life to unmask the logic of scientific inquiry. In addition to his personal experience of scientific practice, his sound knowledge of the history of science and of the history of philosophy helped him to establish a general cartography of scientific methodology. In this sense, following Hookway to a certain extent (1992, 1-3), I think that the most accurate understanding of Peirce's philosophy is to see him as a traditional, systematic philosopher, but one who deals with the modern problems of science, truth and knowledge from a highly valuable personal experience as a logician and as an experimental researcher in the bosom of an international community of scientists and thinkers. Something similar could be said of Artigas: a philosopher who deals with the problems of modern science from the perspective of a very valuable experience as a physicist, deeply involved in establishing a unified field of research among science, reason and faith.

Cambridge, MA: Harvard University Press. [HP] 1985. Historical Perspectives on Peirce's Logic of Science: a History of Science, edited by C. Eisele, Berlin: Mouton. [MS] 1966. The Charles S. Peirce Papers: 32 microfilm reels of the manuscripts kept in the Houghton Library. Cambridge, MA: Harvard University Library, Photographic Service. The manuscripts are quoted by their number in Richard Robin (1967); the letters are identified by the date and an $L$ preceding the number of the folder. [NEM] 1976. The New Elements of Mathematics, edited by C. Eisele. The Hague: Mouton. [W] 1982. Writings of Charles $S$. Peirce: A Chronological Edition, vols. 1-8, edited by The Peirce Edition Project. Bloomington, IN: Indiana University Press. 


\section{What science really is}

Science is for Peirce "a living historic entity" (CP 1.44, c.1896), "a living and growing body of truth" (CP 6.428, 1893), and above all a communicative mode of life. Already in his early years, in "Some Consequences of Four Incapacities" (1868), Peirce had identified the community of inquirers as essential to scientific rationality ( $C P 5.311,1868)$. The flourishing of scientific reason can only take place in the context of research communities: the pursuit of truth is a corporate task and not an individual search for foundations. Throughout his entire life, but especially in his later years, Peirce insisted that the popular image of science as something finished and complete is totally opposite to what science really is, at least in its original practical intent. That which constitutes science "is not so much correct conclusions, as it is a correct method. But the method of science is itself a scientific result. It did not spring out of the brain of a beginner: it was a historic attainment and a scientific achievement" (CP 6.428, 1893).

Scientific growth is not merely the accumulation of data, of registrations, measurements or experiences, but also requires creativity. To learn the truth requires not only collecting data, but also abduction, the adoption of a hypothesis to explain surprising facts, and the deduction of probable consequences which are expected to verify the hypotheses (CP 7.202, 1901). Abduction consists-writes Peirce to Mario Calderoni-in "examining a mass of facts and in allowing these facts to suggest a theory" (CP 8.209, 1905). Though the scientist is invariably a person who is deeply impressed with the efficacy of minute and thorough observations, he or she knows that observing is never enough: "Science, then, may be defined as the business whose ultimate aim is to educe the truth by means of close observation" (HP 1123, 1898).

Here are two beautiful texts by the mature Peirce which define what a science is. The first one is from a 1902 manuscript on the classification of the sciences (MS 1343, 6-7, 1902):

Science is to mean for us a mode of life whose single animating purpose is to find out the real truth, which pursues this purpose by a well-considered 
method, founded on thorough acquaintance with such scientific results already ascertained by others as may be available, and which seeks cooperation in the hope that the truth may be found, if not by any of the actual inquirers, yet ultimately by those who come after them and who shall make use of their results. (also in $C P 7.55,1902$ )

The second text comes from the manuscript of the Adirondack Summer School Lectures and deserves to be quoted a length:

I do not call the solitary studies of a single man a science. It is only when a group of men, more or less in intercommunication, are aiding and stimulating one another by their understanding of a particular group of studies as outsiders cannot understand them, that I call their life a science. It is not necessary that they should all be at work upon the same problem, or that all should be fully acquainted with all that it is needful for another of them to know; but their studies must be so closely allied that any one of them could take up the problem of any other after some months of special preparation and that each should understand pretty minutely what it is that each one of the other's work consists in; so that any two of them meeting together shall be thoroughly conversant with each other's ideas and the language he talks and should feel each other to be brethren. (MS 1334: 11-14, 1905)

There is probably nothing more alien to the present competitive style of science than this conception of scientists working together like brothers, but it is what I learnt from Mariano Artigas. It seems to me that is the task of philosophers: to try to teach this mode of life through the defense of cross-disciplinarity and the advantages of affective relations between colleagues, in a Peircean spirit of agapastic reasonableness (Nubiola 2005).

For Peirce, science is always a process of searching for the truth: "The essence of truth lies in its resistance to being ignored" (CP 2.139, 1902). In contrast to postmodern skepticism and relativism, Peirce's defense of fallibilism does not imply that there is no hope for acquiring sound knowledge, or that it is not possible to reach the truth. Although in the short term the methods of science may produce errors, in the long run they are successful: science is a self-corrective research activity. To Peirce a question "has one 
answer decidedly right, whatever people might think about it" (CP 2.135, 1902), and even error has a positive effect in the journey towards the truth: "The idea of science is to pile the ground before the foot of the outworks of truth with the carcasses of this generation, and perhaps of others to come after it, until some future generation, by treading on them, can storm the citadel" (CP 6.3, 1878).

Peirce's fallibilism does not close the doors to truth, but on the contrary makes it possible to progress towards it. "If I am asked", Peirce writes in another place,

to what the wonderful success of modern science is due, I shall suggest that to gain the secret of that, it is necessary to consider science as living, and therefore not as knowledge already acquired but as the concrete life of the men who are working to find out the truth. Given a body of men devoting the sum of their energies to refuting their present errors, doing away with their present ignorance, and that not so much for themselves as for future generations, and all other requisites for the ascertainment of truth are insured by that one. (CP 7.50, n.d.)

\section{The classification of the sciences}

In a world of ever growing specialization, the idea of the unity of science is commonly discarded as an impossible ideal. Even so, cooperative work involving cross-disciplinary points of view is still encouraged, both as a remedy against the conceptual poverty of the scientific reductionism inherited from the Vienna Circle, and at the same time as a way of efficiently tackling the most stubborn problems facing our society today. Within this framework, I want to emphasize that Charles S. Peirce and Mariano Artigas not only identified this paradoxical situation, but they also mapped out a number of paths for reaching a successful solution. I will pay particular attention to Peirce's classification of the sciences, to his conception of science and to Artigas's vision of interdisciplinarity.

Peirce carefully studied upwards of a hundred different classifications of the sciences and made many attempts to work out his own general classification of the sciences, like so many branches and sub-branches of 
a tree, springing out from one another ( $L$ 75, 1902; HP 805, 1904 and 1124, 1899). Although Peirce supported Auguste Comte's view of each science as a historical development, he disliked Comte's metaphor of the sciences forming "a sort of ladder descending into the well of truth, each one leading on to another, those which are more concrete and special drawing their principles from those which are more abstract and general" (CP 2.119, c.1902). The image of an epistemic ladder of sciences (CP 1.180ff) suggested reductionistic tendencies similar to those of the twentieth-century positivist philosophers of science.

Peirce preferred a natural classification of the sciences, that is, one which embodies "the chief facts of relationships between the sciences so far as they present themselves to scientific and observational study" (MS 1334, 1905). And Peirce continues asking himself, "What is a science as a natural object?" His answer is essential for us: "It is the actual living occupation of an actual group of living men". To Peirce science is not "systematic knowledge", but

the life devoted to the pursuit of truth according to the best known methods on the part of a group of men who understand one another's ideas and works as no outsider can. It is not what they have already found out which makes their business a science; it is that they are pursuing a branch of truth according, I will not say, to the best methods, but according to the best methods that are known at the time. (MS 1334: 12)

Each community of scientists grows up around specific ways of perceiving, certain special methods of research. Each science corresponds to a special kind of observation which distinguishes the mode of thought of the students of each special branch (CP 1.100). Scientists are

men who spend their lives in finding out similar kinds of truth about similar things, [and who] understand what one another are about better than outsiders do. They are all familiar with words which others do not know the exact meaning of, they appreciate each other's difficulties and consult one another about them. They love the same sort of things. They consort together and consider one another as brethren. They are said to pursue the same branch of science. (NEM 804-5) 
I will not go into the details of Peirce's classification of sciences. Nevertheless, I want to stress that the texts selected are strikingly relevant to our contemporary views regarding the nature of science, because they shift the emphasis of the discussion from the view of sciences as objects to be classified towards the lives of real men and women involved in scientific research. Indeed, in Peirce's view, the sciences of discovery are to be identified with the lives of their practitioners. To illustrate this point, I want to quote another long text, also from the Adirondack Summer School Lectures:

All human lives separate themselves and segregate themselves into three grand groups whose members understand one another in a general way, but can['t] for the life of them understand sympathetically the pursuits and aims of the others. The first group consists of the devotees of enjoyment who devote themselves to carving their bread and eating as fine bread as they can and who seek the higher enjoyments of themselves and their fellows. This is the largest and most necessary class. The second group despises such a life and cannot fully understand it. Their notion of life is to accomplish results. They build up great concerns, they go into politics [...] This group makes civilization. The men of the third group who are comparatively few cannot conceive at all a life for enjoyment and look down upon a life of action. Their purpose is to worship God in the development of ideas and of truth. These are the men of sciences. (MS 1334, pp. 11-14, 1905)

The text continues with the division of men of science according to their different conceptions of the purpose of science. In this context, Peirce distinguishes the Practical Sciences from the Sciences of Review, and then adds a third group which he calls the heuretics or heurospudists. These are the men who endeavor to discover, and who "look upon discovery as making acquaintance with God and as the very purpose for which the human race was created" (MS 1334, 20, 1905). This may sound a little strange to modern, positivist ears, but it is closely related to Peirce's religious concerns, which are as philosophically important as his scientific concerns (Parker 1998, 231, n. 5). Something very similar could be said-or at least so it seems to me-of Mariano Artigas. 


\section{Peirce and Artigas on cross-disciplinarity}

As I said above, Peirce defined science as a diligent inquiry into truth for truth's sake, developed by a community of inquirers skilled in the manipulation of particular instruments, and trained in certain ways of perceiving or particular modes of thought. Sciences are traditions of research developed in time and space. For Peirce, "science does not advance by revolutions, warfare, and cataclysms, but by cooperation, by each researcher's taking advantage of his predecessors' achievements, and by his joining his own work in one continuous piece to that already done" (CP 2.157, c.1902). Science is a way of life, a craft handed down from master to apprentice.

For this reason, the key to the advancement of knowledge and to the development of sciences is not revolution, but communication. Communication between the members of a science community is essential for scrutinizing the evidence and the results achieved in research. There is no algorithm-no routine or unfailing method-for discovering the truth or knowing for sure when you have it. Thus, truth and knowledge-at least in the hard sciences-are located at the level of the scientific community rather than the individual inquirer (Ransdell 1998). More specifically, Peirce clearly asserts that the scientific community, far from being an assembly or a parliament whose members fight each other with fierce arguments, should be more like a family. "A given science with a special name, a special journal, a special society, studying one group of facts, whose students understand one another in a general way and naturally associate together, forms what I call a family" (CP 1.238, c.1902). A scientific community is always-or at least should be, according to Peirce-an affective community.

A second point of interest is the encouragement of cross-disciplinarity between sciences: "One of the most salient phenomena of the life of science is that of a student of one subject getting aid from students of other subjects" (HP 805, 1904). It is not only that "the higher places in science in the coming years are for those who succeed in adapting the methods of one science to the investigation of another. That is what the greatest progress of the passing generation has consisted in" (CP 7.66, 1882), but that new 
knowledge is generated wherever communication between different branches of science is enhanced.

Mariano Artigas held that nowadays we are in a privileged situation for communicating and working cross-disciplinarily between science and philosophy, thanks to the development of contemporary philosophy of science. In his 2001 seminar "Mi visión de la interdisciplinariedad", ${ }^{3}$ Artigas explained that until the early twentieth century, the philosophy of science was a hobby of a few philosophers and scientists. The Vienna Circle gave it a boost both in Europe and in the United States, albeit with a serious positivist bias that has been evolving gradually.

At present-concluded Artigas-we have undertaken important studies from the points of view of logic, sociology, history and methodology. Along with the remarkable development of many scientific disciplines, these studies provide sufficient evidence to build a balanced philosophy of science, corresponding to science as it exists in reality, while at the same time it leads us deep into philosophical problems with some guarantee of success. According to Artigas this privileged situation makes it possible to arrange a fruitful dialogue between sciences, philosophy and theology. With great respect for the peculiarities and autonomy of each kind of knowledge, philosophy may provide a common ground for this dialogue.

Artigas' central idea is that experimental science includes not only the statements, theories and models formulated in each discipline, but also some conditions that make possible the existence and progress of the scientific enterprise. According to him, there are three such presuppositions: a) the existence of an intelligible natural order (ontological presupposition); b) the human capacity for knowing that order (epistemological presupposition); and c) the value of the goal that makes pursuing the scientific enterprise worthwhile (ethical presupposition). Artigas and other authors hold that scientific progress justifies these three assumptions backwards, enlarging

3 The text of the Grupo de Estudios Peirceanos Seminar held on 17 May 2001 is available at <http://www.unav.es/gep/MiVisionInter.html>. Most of the ideas presented in the seminar are explained by Artigas with more detail in his book The Mind of the Universe: Understanding Science and Religion (2000). 
them and making them more accurate. Artigas labels these presuppositions as pragmatic rather than logical, and are necessary conditions of the scientific enterprise (2000, 52).

For Artigas, the protagonist of the dialogue should be philosophy, which is the natural bridge for a fruitful dialogue between scientific disciplines and metaphysical questions. In a similar vein, Peirce holds that philosophy, pursued in the spirit of the laboratory, is precisely the tradition of research that can build those bridges between disciplines. In contrast to science, which grows based on special experience, philosophy is "that science which limits itself to finding out what it can from ordinary everyday experience, without making any special observations" (HP 825, 1904).

While special sciences grow in laboratories or in very sophisticated contexts of research, the laboratory of the philosopher is our ordinary experience, our real lives even while in academic environments. From a Peircean perspective, communication between the branches of science is the effect of the efforts of a real community of human beings trying to share their discoveries. Each scientist must commit to being a kind of philosopher, avid to learn from the other branches and, while reflecting on the peculiar experience around which his or her own branch has developed, also trying to make sense of the entire tree of knowledge through dialogue with other disciplines.

\section{Conclusion}

According to both Charles S. Peirce and Mariano Artigas, science is a collective and cooperative activity involving all those whose lives are animated by the desire to discover the truth. The particular sciences are branches of a common tree. The unity of science is not achieved by the reduction of special sciences to more basic ones. The new name for the unity of the sciences is cross-disciplinarity; not the union of the sciences themselves, but rather the unity and dialogue of the scientists, the real inquirers into the truth.

According to Peirce and Artigas, philosophers are in the right position to call for the unity of sciences. This call should not be seen as a return to 
the old and stale scientism, but as an invitation to a deep dialogue between particular sciences and philosophy in order to investigate the presuppositions of the scientific enterprise. The key to the cross-disciplinarity of knowledge is not revolution, but rather the practice of sharing efforts in a unique mixture of continuity and fallibilism, of affection and reason, of the attempt to understand others as well as oneself, by putting oneself in the shoes of others and walking several miles with them on.

\section{References}

Artigas, M. 2000. The Mind of the Universe: Understanding Science and Religion. Radnor, PA: Templeton Foundation Press.

-. 2001. "Mi visión de la interdisciplinariedad." Grupo de Estudios Peirceanos, Seminar 17 May 2001, Available at <http://www.unav.es/gep/MiVisionInter.html> Fisch, M. H. 1993. Introduction to $W$ 3. xxi-xxxvii. Bloomington, IN: Indiana University Press.

Hookway, C. 1992. Peirce. Routledge: London.

Ketner, K. L. 2009. “Charles Sanders Peirce: Interdisciplinary Scientist.” In The Logic of Interdisciplinarity, by C. S. Peirce, edited by E. Bisanz, 35-57. The Monist-Series, Berlin: Akademie.

Lenzen, V. F. 1964. “Charles S. Peirce as Astronomer.” In Studies in the Philosophy of Charles Sanders Peirce, Second Series, edited by E. C. Moore, and R. Robin, 33-50. Amherst, MA: University of Massachusetts Press.

Nubiola, J. 2005. "The Classification of the Sciences and Cross-disciplinarity." Transactions of the Charles S. Peirce Society 41:271-82.

-. 2014. "What a Scientific Metaphysics Really is According to Charles S. Peirce." Cognitio 15:349-58.

Nubiola, J., and S. Barrena. 2014. "Science as a Communicative Mode of Life." In The Peirce Quote Book: Charles Sanders Peirce in His Own Words, edited by T. Thellefsen, and B. Sørensen, 437-442. Berlin: Mouton de Gruyter.

Parker, K. A. 1998. The Continuity of Peirce's Thought. Nashville, TN: Vanderbilt University Press.

Peirce, C. S. 1931-1958. Collected Papers of Charles Sanders Peirce, vols. 1-8, edited by C. Hartshorne, P. Weiss, and A. W. Burks. Cambridge, MA: Harvard University Press. [CP]

-. 1985. Historical Perspectives on Peirce's Logic of Science: a History of Science, edited by C. Eisele, Berlin: Mouton. [HP] 
-. 1966. The Charles S. Peirce Papers: 32 microfilm reels of the manuscripts kept in the Houghton Library. Cambridge, MA: Harvard University Library, Photographic Service. [MS]

-. 1976. The New Elements of Mathematics, edited by C. Eisele. The Hague: Mouton. [NEM]

-. 1982. Writings of Charles S. Peirce: A Chronological Edition, vols. 1-8, edited by The Peirce Edition Project. Bloomington, IN: Indiana University Press. [W] Ransdell, J. 1998. “Sciences as Communicational Communities.” Arisbe: The Peirce Gateway. Available at http://members.door.net/arisbe/menu/library/aboutcsp/ ransdell/physics.htm

Robin, R. 1967. Annotated Catalogue of the Papers of Charles S. Peirce. Amherst, MA: University of Massachusetts Press. 